\title{
A new method for tourism carrying capacity assessment
}

\author{
V. Castellani, S. Sala \& D. Pitea \\ University of Milano Bicocca, Department of Environmental Sciences, \\ Italy
}

\begin{abstract}
Tourism activities can generate both positive and negative effects on the conditions of the areas where visiting and fruition activities take place; every form of human use of natural environment causes changes to the environment conditions. Evaluation of carrying capacity of a destination has as a purpose the measurement of the threshold over which alteration due to human activities becomes unacceptable. To evaluate the consequences of tourism activities impacts it is necessary to know the characteristics of the environment where they occur and especially its resilience, which is the measure of the disturbance that the natural environment can tolerate without altering its equilibrium state. The carrying capacity concept is linked with resilience and rises from the necessity of measure which is the maximum acceptable level of impact for the environment or for one of its components and the capability of recovery of the previous condition. The purpose of this study is to suggest a model for assessing the physical carrying capacity of tourism destinations, as a tool to evaluate whether the current situation is sustainable or not and to determine if a rise in visitor numbers could affect the quality of the environment, the resources available and the quality of public services. For the assessment, all environmental aspects are separately analysed and the main environmental issues related to the daily life of residents and to tourism activities (air quality, water quality and disposability, waste management, soil use) are considered. The methodology is based on an evaluative procedure inspired by the DPSIR model, useful for underlining which are the drivers of impacts and which is the most relevant dataset to describe current and future scenarios. The innovative aspect of this study is the integration of the physical carrying capacity assessment with the evaluation of the managing capacity of environmental and public services, which can lead to depletion of ecosystem quality.
\end{abstract}

Keywords: tourism, carrying capacity, destination management, DPSIR model. 


\section{Introduction}

Tourism activities can generate both positive and negative effects on the conditions of the areas where visiting and fruition activities take place; every form of human activity causes changes of environmental conditions; the purpose of the evaluation of carrying capacity of a destination is the measurement of the threshold over which alteration due to human activities becomes unacceptable for the resource recovery. To evaluate consequences of tourism activities impact is necessary to know the characteristics of the environment where they insist on and especially its resilience, which is the measure of the disturbance that natural environment can tolerate without altering its state of equilibrium. Carrying capacity concept is linked with resilience and rises from the necessity of measure which is the maximum acceptable level of impact for the environment or for one of its components and the capability of recovery of previous condition (Holling [6]).

World Tourism Organization has defined Tourism Carrying Capacity as "the maximum number of persons which could visit a location within a given period, such that local environmental, physical, economic, and socio-cultural characteristics are not compromised, and without reducing tourist satisfaction" (WTO, [12]). Thus, physical (or ecological), social and economic carrying capacity can be defined as follow:

- Physical (or ecological) carrying capacity is the threshold limit beyond which natural and cultural heritage of a destination are damaged by tourism; physical carrying capacity of a destination is thence determined through the analysis of its environmental components (for example, water resources quantity and availability, limits for air pollutants concentrations) and through the analysis of the facilities required by both tourists and residents: saturation limits for existing facilities (for example, sewage treatment plants, waste treatment plants) and limits for new facilities construction.

- Economic carrying capacity is the threshold limit beyond which tourism growth becomes economically unacceptable; this situation may rise from two conditions: a) when tourism interfere with other economic activities obstructing their development, b) when the presence of a great number of tourists makes the destination no more comfortable and attractive and causes a contraction in tourism demand.

- Social carrying capacity is the threshold beyond which social aspects of the host community are badly influenced and damage by tourism activities and life's quality of residents is no more granted; this situation can also lead to conflicts between tourists and resident population, generating social tensions.

In this paper a study of physical carrying capacity of a tourist destination is presented, applied to Oltrepo Mantovano area, in northern Italy. The innovative aspect of this study is the integration of physical carrying capacity assessment with the evaluation of managing capacity of environmental and public services, which could lead to depletion of ecosystems quality. 
Oltrepo Mantovano is an interesting area of application because it is a newly emerging tourism destination according to the tourism area Life Cycle Model (Agarwal [1], Butler [4], Miossec [11]) and also because protected areas of Oltrepo Mantovano have undertaken European Charter for Sustainable Tourism in Protected Areas, a process promoted by Europarc (the European Federation of Parks), with the aim of assuring environmental conservation and promoting economic and social development through a sustainable tourism strategy.

Assessing carrying capacity in this area is thence an effort to provide a useful tool to decision makers (i.e. local administrators and park managers) that are now planning tourism development policy for future years, trying to promote sustainable development and prevent adverse effect on the environment.

\section{Methodology}

The methodology is based on an evaluative procedure inspired to DPSIR model, useful to underline which are the drivers of impacts and which is the most useful dataset to describe current and future scenarios. For carrying capacity assessment, all environmental aspects are separately took into account and main environmental issues related to daily life of residents and to tourism activities (air quality, water quality and disposability, waste management, soil use) are considered.

The methodology aims to integrate physical carrying capacity assessment with the evaluation of managing capacity of environmental and public services. This approach is based on the consciousness that two major types of impact can be identified in a tourist destination: those with are associated with tourism structures (hotels, roads and other facilities) and those resulting from the tourists themselves (crowding of natural sites, air and water pollution) (May [9]).

The analysis of tourism sector based on DPSIR model allows one to identify main issues related to tourism activities and to address tourism carrying capacity assessment.

Table 1: $\quad$ DPSIR model for tourism sector.

\begin{tabular}{|l|l|}
\hline Drivers & $\begin{array}{l}\text { Construction and management of hospitality structures and facilities, } \\
\text { presence of tourists, urban traffic. }\end{array}$ \\
\hline Pressures & $\begin{array}{l}\text { Emissions of air pollutants, use of groundwater resources, immission } \\
\text { of pollutants in stream waters, production of solid urban waste, land } \\
\text { use and soil erosion, energy consumption, presence of tourists in } \\
\text { protected areas. }\end{array}$ \\
\hline State & $\begin{array}{l}\text { Concentration of pollutant in air and water, groundwater availability, } \\
\text { quantity of solid urban waste, level of urbanization, level of crowding } \\
\text { in natural sites. }\end{array}$ \\
\hline Impacts & $\begin{array}{l}\text { Loss of biodiversity, disturb of wild species, adverse effects on } \\
\text { human health. }\end{array}$ \\
\hline Responses & $\begin{array}{l}\text { Promotion of sustainable tourism: reduction of water and energy } \\
\text { consumption, reduction of waste production and increasing of } \\
\text { separated waste collection, promotion of public transports, use of } \\
\text { renewable energy, promotion of ecotourism activities. }\end{array}$ \\
\hline
\end{tabular}


Evaluation phases, used for every issue, are:

1. Selection of the issue and characterization of the drivers related to it

2. Selection of drivers relevant for the issue in tourism contest

3. Identification of main pressures

4. Development/application of specific indicators for identified pressures

5. Set up of benchmark values, minimum and maximum, and definition of classes for the result. Selection of benchmark values is based on:
a. literature
b. limit values determined by European and Italian laws
c. benchmarking with other situations

6. Collection of local data and data processing

7. Evaluation of carrying capacity of the issue, based on benchmarking among considered variables; for the evaluation, precautionary principle is adopted: worst case is taken into account and, if one variable is near the limit, low carrying capacity is attributed to the entire compartment.

8. Elaboration of the results to select appropriate responses for short or long term solution of main problems identified, which can be performed by public and private administrators and by tourists themselves, in a shared responsibility perspective.

\section{Results}

Oltrepo Mantovano is a plain area, with low population density and little urban centres. Industrialization is not very high, but the presence of two electric power plants strongly characterises the area, both from industrial and environmental perspective. Protected areas are mainly homes near Po river with seminatives and timbers and have high ecological value: part of the areas is classified as Important Bird Areas (IBA) and there are also many endemic species (e.g. Lataste's frog).

Table 2 shows an example of a detailed scheme, developed for each compartment, applied to Oltrepo Mantovano area.

The previous conceptual scheme, applied to all compartment considered, gives an overall evaluation of tourism carrying capacity in Oltrepo Mantovano. The main results are presented in table 3 .

\section{Discussion}

Results of tourism carrying capacity of Oltrepo Mantovano, though not completely exhaustive, show that the situation is critical for some aspects, suggesting that a sustainable tourism policy for the future should take into account the necessity of some actions to prevent environmental damage and arise of problems for environmental and public services management.

Issues that have a low (or very low) carrying capacity rank are groundwater disposability and air quality. This result is to take into serious account in view of a tourism development because both this issues could be seriously affected by a 
Table 2: $\quad$ Methodology for air carrying capacity assessment.

\begin{tabular}{|c|c|c|}
\hline DPSIR & METHODOLOGY & LOCAL RESULTS \\
\hline 1) DRIVERS & $\begin{array}{l}\text { Analysis of datasets of } \\
\text { emissions sources aimed to } \\
\text { identify which sources / } \\
\text { activities are most relevant in } \\
\text { the area object of the } \\
\text { investigation. }\end{array}$ & $\begin{array}{l}\text { Analysis of data from Inemar } \\
\text { Lombardy Region inventory of } \\
\text { emission sources: main drivers for } \\
\text { Oltrepo Mantovano are: electric } \\
\text { power generation (electric power } \\
\text { plants), non industrial combustion } \\
\text { (heating) and urban traffic, which } \\
\text { cause emissions of } \mathrm{PM}_{10}, \mathrm{CO}_{2}, \mathrm{COV} \text {, } \\
\mathrm{NO}_{\mathrm{x}}, \mathrm{SO}_{2} \text { and } \mathrm{CO} \text {. }\end{array}$ \\
\hline $\begin{array}{ll}\text { 2) DRIVERS } & \text { AND } \\
\text { VARIABLES } & \\
\text { RELEVANT } & \text { FOR } \\
\text { TOURISM } & \\
\text { SECTOR } & \end{array}$ & $\begin{array}{l}\text { From the drivers set identified } \\
\text { in step } 1 \text {, selection of drivers } \\
\text { which are most relevant for } \\
\text { tourism sector. }\end{array}$ & $\begin{array}{l}\text { The emission source most relevant for } \\
\text { tourism sector evaluation in Oltrepo } \\
\text { Mantovano is urban traffic, because } \\
\text { electric power generation is an } \\
\text { industrial activity, not strictly linked } \\
\text { with local consumption and heating } \\
\text { becomes not relevant during high } \\
\text { tourist seasons (spring-summer). }\end{array}$ \\
\hline 3) PRESS & $\begin{array}{l}\text { Selection of main pressures } \\
\text { generated by identified } \\
\text { driver/s. }\end{array}$ & $\begin{array}{l}\text { Urban traffic generates emissions of } \\
\mathrm{PM}_{10}, \mathrm{CO}, \mathrm{COV} \text { and } \mathrm{NO}_{\mathrm{x}} \text {. } \\
\text { ARPA monitoring network registers } \\
\text { periodically the values of } \\
\text { concentration of } \mathrm{PM}_{10}, \mathrm{CO} \text { and } \mathrm{NO}_{2} \text {; } \\
\text { data of COV concentrations are not } \\
\text { available. }\end{array}$ \\
\hline TORS & $\begin{array}{l}\text { Selection of appropriate } \\
\text { indicators to measure state. } \\
\text { Indicator used by European } \\
\text { and Italian legislation to } \\
\text { evaluate air pollution level is } \\
\text { the number of daily } \\
\text { overcoming of limit } \\
\text { concentration during a year. }\end{array}$ & $\begin{array}{l}\text { a) number of overcoming for } \mathrm{PM}_{10} \\
\text { concentration in Oltrepo Mantovano; } \\
\text { limit value: } 35 \text { days of } \\
\text { overcoming/year. } \\
\text { b) number of overcoming for } \mathrm{NO}_{2} \\
\text { concentration in Oltrepo Mantovano; } \\
\text { limit value: } 35 \text { days of } \\
\text { overcoming/year. } \\
\text { A limit for CO is not fixed because } \\
\text { this pollutant is no longer a problem } \\
\text { in Italy. }\end{array}$ \\
\hline $\begin{array}{l}\text { 5) STATE } \\
\text { CLASSES }\end{array}$ & $\begin{array}{l}\text { On the base of indicators and } \\
\text { limit identified in the } \\
\text { previous step, classes of } \\
\text { carrying capacity are fixed. }\end{array}$ & $\begin{array}{l}\text { a) } \mathrm{nr} \text { of overcoming for } \mathrm{PM}_{10}<10 \text { : } \\
\text { HIGH carrying capacity } \\
\mathrm{nr} \text { of overcoming for } \mathrm{PM}_{10}=35 \text { : } \\
\text { LIMIT of carrying capacity } \\
\mathrm{nr} \text { of overcoming for } \mathrm{PM}_{10}>35 \text { : } \\
\text { LOW carrying capacity } \\
\mathrm{nr} \text { of overcoming for } \mathrm{PM}_{10} \gg 35 \text { : } \\
\text { VERY LOW carrying capacity } \\
\text { b) } \mathrm{nr} \text { of overcoming for } \mathrm{NO}_{2}<10 \text { : } \\
\mathrm{HIGH} \text { carrying capacity } \\
\mathrm{nr} \text { of overcoming for } \mathrm{NO}_{2}=18 \text { : } \\
\text { LIMIT of carrying capacity } \\
\text { nr of overcoming for } \mathrm{NO}_{2}>18 \text { : LOW } \\
\text { carrying capacity } \\
\text { nr of overcoming for } \mathrm{NO}_{2} \gg 18 \text { : } \\
\text { VERY LOW carrying capacity }\end{array}$ \\
\hline $\begin{array}{l}\text { 6) LOCAL } \\
\text { RESULT }\end{array}$ & $\begin{array}{l}\text { Analysis of local data about } \\
\text { indicators identified. }\end{array}$ & $\begin{array}{l}\mathrm{nr} \text { of overcoming for } \mathrm{PM}_{10}: 108 \\
\mathrm{nr} \text { of overcoming for } \mathrm{NO}_{2}: 1\end{array}$ \\
\hline
\end{tabular}


Table 2: $\quad$ Continued.

\begin{tabular}{|l|l|l|}
\hline 7) CARRYING & $\begin{array}{l}\text { Carrying capacity assessment, } \\
\text { based on classes identified } \\
\text { and data collected; carrying } \\
\text { capacity level of the entire } \\
\text { compartment is assigned } \\
\text { according to precautionary } \\
\text { principle. }\end{array}$ & $\begin{array}{l}\text { a) } \text { PMO }_{10} \text { : VERY LOW } \\
\text { Carrying capacity of the issue: VERY } \\
\text { LOW }\end{array}$ \\
\hline 8) RESPONSES & $\begin{array}{l}\text { Elaboration of the results to } \\
\text { select responses for main } \\
\text { problems identified }\end{array}$ & $\begin{array}{l}\text { Promote public transport and tourist } \\
\text { offers for discouraging use of private } \\
\text { car by tourists. }\end{array}$ \\
\hline
\end{tabular}

raise in the number of tourists: indeed groundwater is the main source of drinking water in the area and moreover Oltrepo Mantovano is in the critical area of Lombardy Region and the difficulties of using public transport to move in the area (as the high percentage of tourists reaching the destination with private cars confirm) may cause an additional decline of air quality situation in case of increase of tourists number.

Besides, carrying capacity is at limit for some other important issues, both from environmental and managing perspective: ecological status of stream waters and percentage of separated waste disposal are now sufficient, but both the natural resources and public services would be not able to manage additional load coming from the increasing of tourism impacts.

Regarding current situation, main critical aspect, not directly depending from local policy management, seems to be the ratio between daily visitors and resident tourists: daily visitors, that are proved to generate more impacts on the environment and cause more consumption of resources rather than resident tourists (Beltrame et al [3]) are currently twice the number of resident tourists in Oltrepo Mantovano.

\section{Conclusions}

The main critical aspect associated with carrying capacity assessment of tourism destination is the complexity of providing numeric results (Bimonte and Punzo [2]). Following Manning point of view [10], this study is an attempt to quantify current state of every compartment involved in tourism management and give a quantity perspective on present and future scenarios of destination development considering environmental, social and economical indicators.

The main difficulties emerging from this application of the methodology are:

- necessity of setting precise values that are widely recognises as thresholds of sustainability, could be a quite controversial aspect: a good solution seems to be the use of law limits, but these are not available for all issues: in this case, further investigation, also considering local contest and expert judgement, could be required. European Charter for Sustainable Tourism in Protected Areas is a good tool for this purpose, because the process strongly encourage the involvement of local stakeholders; 
Table 3: Results of Oltrepo Mantovano tourism carrying capacity assessment.

\begin{tabular}{|c|c|c|c|c|c|}
\hline & Indicator & & State / classes & Value & $\begin{array}{l}\text { Carrying } \\
\text { capacity }\end{array}$ \\
\hline \multirow{3}{*}{$\begin{array}{l}\text { Disposability of } \\
\text { groundwater }\end{array}$} & \multirow{3}{*}{$\begin{array}{l}\text { withdrawal / } \\
\text { recharge } \\
\left(\mathrm{m}^{3} / \mathrm{g}\right) /\left(\mathrm{m}^{3} / \mathrm{g}\right)\end{array}$} & (;) & $<1$ & \multirow{3}{*}{1,35} & \multirow{3}{*}{$\ddot{\theta}$} \\
\hline & & $\odot$ & $=1$ & & \\
\hline & & : & $>1$ & & \\
\hline \multirow{9}{*}{$\begin{array}{l}\text { Quality of } \\
\text { stream water }\end{array}$} & \multirow{3}{*}{$\begin{array}{l}\text { people served } \\
\text { by sewage } \\
\text { disposal } \\
\text { (people } \\
\text { served/people } \\
\text { resident) } * 100 \\
\end{array}$} & (;) & $100 \%-75 \%$ & \multirow{3}{*}{$75 \%$} & \multirow{3}{*}{$(\dot{)}$} \\
\hline & & $\odot$ & $75 \%-50 \%$ & & \\
\hline & & 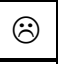 & $<50 \%$ & & \\
\hline & \multirow{3}{*}{$\begin{array}{l}\text { potential P.E. / } \\
\text { actual P.E. }\end{array}$} & (;) & $>1$ & \multirow{3}{*}{$>1$} & \multirow{3}{*}{ (:) } \\
\hline & & :) & $=1$ & & \\
\hline & & : & $<1$ & & \\
\hline & \multirow{3}{*}{ 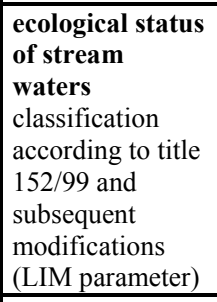 } & (;) & excellent, good & \multirow{3}{*}{ sufficient } & \multirow{3}{*}{$\bigodot$} \\
\hline & & 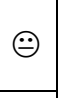 & sufficient & & \\
\hline & & $\theta$ & bad, awful & & \\
\hline \multirow{3}{*}{$\begin{array}{l}\text { Energetic } \\
\text { consume }\end{array}$} & \multirow{3}{*}{$\begin{array}{l}\text { mean energetic } \\
\text { consume } \\
\text { (municipality } \\
\text { level) / mean } \\
\text { energetic } \\
\text { consume } \\
\text { (national level) } \\
\text { (MWh/residents) }\end{array}$} & (;) & $<1$ & \multirow{3}{*}{$<1$} & \multirow{3}{*}{$(-)$} \\
\hline & & 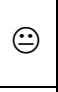 & $=1$ & & \\
\hline & & : & $>1$ & & \\
\hline \multirow{6}{*}{$\begin{array}{c}\text { Waste } \\
\text { management }\end{array}$} & \multirow{3}{*}{$\begin{array}{l}\text { daily per capita } \\
\text { production } \\
(\mathrm{kg} / \text { residents } * \mathrm{~d})\end{array}$} & (;) & $1,8-2,2 \mathrm{Kg} /$ res$^{*} \mathrm{~d}$ & \multirow{3}{*}{1,6} & \multirow{3}{*}{$(\dot{)}$} \\
\hline & & $\oplus$ & $2,2-2,5 \mathrm{Kg} / \mathrm{res} * \mathrm{~d}$ & & \\
\hline & & 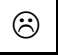 & $>2,5 \mathrm{Kg} / \mathrm{res}^{*} \mathrm{~d}$ & & \\
\hline & \multirow{3}{*}{$\begin{array}{l}\% \text { of separated } \\
\text { waste disposal }\end{array}$} & (;) & $>45 \%$ & \multirow{3}{*}{$39,80 \%$} & \multirow{3}{*}{$\bigodot$} \\
\hline & & 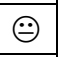 & $35-45 \%$ & & \\
\hline & & $\theta$ & $<35 \%$ & & \\
\hline
\end{tabular}


Table 3: $\quad$ Continued.

\begin{tabular}{|c|c|c|c|c|c|}
\hline Air quality & $\begin{array}{l}\text { mean number } \\
\text { of overcoming } \\
\text { of law } \\
\text { thresholds / } \\
\text { year }\end{array}$ & $\begin{array}{l}\text { limit } \\
\text { not } \\
\text { over } \\
\text { Pm } \\
\text { not } \\
\text { over }\end{array}$ & $\begin{array}{l}\text { value: } \\
\text { over } 35 \text { days of } \\
\text { coming/year for } \\
\text {; } \\
\text { over } 18 \text { days of } \\
\text { taking/year for } \mathrm{NO}_{2}\end{array}$ & $\begin{array}{c}\mathrm{PM}_{10}: 108 \\
\mathrm{NO}_{2}: 1\end{array}$ & $\ddot{\theta} \ddot{0}$ \\
\hline Biodiversity & $\begin{array}{l}\text { loss of species, } \\
\text { disturb } \\
\text { number of } \\
\text { visitors/year } \\
\end{array}$ & $\begin{array}{l}\text { no } \\
\text { judg } \\
\text { expe }\end{array}$ & $\begin{array}{l}\text { classes, expert } \\
\text { ement of local } \\
\text { rts }\end{array}$ & $\begin{array}{l}4.000- \\
5.000\end{array}$ & (:) \\
\hline \multirow{18}{*}{ Soil use } & \multirow{3}{*}{$\begin{array}{l}\text { hospitality } \\
\text { density } \\
\text { beds / } 1000 \\
\text { residents }\end{array}$} & (;) & $0-100$ & \multirow{3}{*}{13,71} & \multirow{3}{*}{$(\dot{)}$} \\
\hline & & $\odot$ & $10-300$ & & \\
\hline & & $\theta$ & $>300$ & & \\
\hline & \multirow{3}{*}{$\begin{array}{l}\text { hospitality } \\
\text { density } \\
\text { extension of } \\
\text { hospitality } \\
\text { structures/total } \\
\text { extension of } \\
\text { tourist area }\end{array}$} & (:) & $0 \%-30 \%$ & \multirow{3}{*}{$0,001 \%$} & \multirow{3}{*}{$(-)$} \\
\hline & & 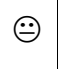 & $30 \%-60 \%$ & & \\
\hline & & 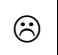 & $>60 \%$ & & \\
\hline & \multirow{3}{*}{$\begin{array}{l}\text { tourist } \\
\text { buildings } \\
\text { non hotel } \\
\text { structures / total } \\
\text { hospitality } \\
\text { structures }\end{array}$} & ;) & $>20 \%$ & \multirow{3}{*}{$54,20 \%$} & \multirow{3}{*}{ (ن) } \\
\hline & & 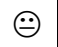 & $10 \%-20 \%$ & & \\
\hline & & ; & $<10 \%$ & & \\
\hline & \multirow{3}{*}{$\begin{array}{l}\text { Houses not used } \\
\text { by residents / } \\
\text { total of houses }\end{array}$} & (:) & $<20 \%$ & \multirow{3}{*}{$8 \%$} & \multirow{3}{*}{ (ن) } \\
\hline & & 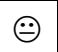 & $20 \%-50 \%$ & & \\
\hline & & : & $>50 \%$ & & \\
\hline & \multirow{3}{*}{$\begin{array}{l}\text { crowding of } \\
\text { natural sites } \\
\text { and paths } \\
\text { (expert } \\
\text { judgement) }\end{array}$} & (;) & low & \multirow{3}{*}{ Low } & \multirow{3}{*}{ (:) } \\
\hline & & 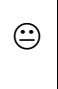 & mean & & \\
\hline & & : & high & & \\
\hline & \multirow{3}{*}{$\begin{array}{l}\text { daily } \\
\text { visitors/tourists }\end{array}$} & (:) & $\mathrm{I}<1$ & \multirow{3}{*}{$>2$} & \multirow{3}{*}{$\ddot{\theta}$} \\
\hline & & 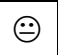 & $1<\mathrm{I}<2$ & & \\
\hline & & : & $\mathrm{I}>2$ & & \\
\hline
\end{tabular}


Table 3: $\quad$ Continued.

\begin{tabular}{|c|c|c|c|c|c|}
\hline \multirow{3}{*}{$\begin{array}{l}\text { Use of existing } \\
\text { structures }\end{array}$} & \multirow{3}{*}{$\begin{array}{l}\text { [overnights / } \\
\text { (beds*365)] * } \\
100\end{array}$} & (;) & $<20 \%$ & \multirow{3}{*}{30,76} & \multirow{3}{*}{$\odot$} \\
\hline & & $\odot$ & $20 \%-40 \%$ & & \\
\hline & & 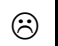 & over $40 \%$ & & \\
\hline \multirow{9}{*}{ Mobility } & \multirow{3}{*}{$\begin{array}{l}\% \text { of tourists } \\
\text { reaching the } \\
\text { area with } \\
\text { private cars }\end{array}$} & (;) & $<40 \%$ & \multirow{3}{*}{$>70 \%$} & \multirow{3}{*}{$\ddot{\theta}$} \\
\hline & & 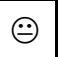 & $40 \%-70 \%$ & & \\
\hline & & : & $>70 \%$ & & \\
\hline & \multirow{3}{*}{$\begin{array}{l}\text { Number of } \\
\text { private } \\
\text { cars/residents }\end{array}$} & (;) & $0-0,3$ & \multirow{3}{*}{0,59} & \multirow{3}{*}{$\ddot{\theta}$} \\
\hline & & $\odot$ & $0,3-0,5$ & & \\
\hline & & $:$ & $0,5-0,8$ & & \\
\hline & \multirow{3}{*}{$\begin{array}{l}\text { Number of } \\
\text { municipalities } \\
\text { with a railway } \\
\text { station }\end{array}$} & (;) & $0,8-1$ & \multirow{3}{*}{0,6} & \multirow{3}{*}{$\odot$} \\
\hline & & $\oplus$ & $0,4-0,7$ & & \\
\hline & & : & $0-0,3$ & & \\
\hline \multirow{3}{*}{$\begin{array}{c}\text { Tourist } \\
\text { intensity in } \\
\text { peak month }\end{array}$} & \multirow{3}{*}{$\begin{array}{l}\text { (overnights in } \\
\text { august/31days) / } \\
\text { residents }\end{array}$} & (:) & $\mathrm{I}<0,5$ & \multirow{3}{*}{0,002} & \multirow{3}{*}{ 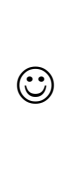 } \\
\hline & & $\odot$ & $0,5<\mathrm{I}>1$ & & \\
\hline & & 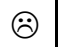 & $\mathrm{I}>1$ & & \\
\hline $\begin{array}{c}\text { Tourist } \\
\text { employment }\end{array}$ & $\begin{array}{l}\text { Employed in } \\
\text { tourism sector / } \\
\text { total employed }\end{array}$ & $\begin{array}{l}\text { no } \\
\text { judg } \\
\text { expe }\end{array}$ & 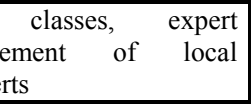 & $3,14 \%$ & (ن) \\
\hline
\end{tabular}

- difficulty to find data for a multi-year period;

- difficult to obtain exhaustive results for all considered compartment.

Moreover, regarding the themes considered in tourism carrying capacity assessment, most critical issues seem to be: consumption of energy, for which there is a lack of data in Italian statistic dataset at local level, and impacts on biodiversity.

Data of local energy consumption available in Italy refers to 1997, because it is the last year of national management of energy market: from 1998 in Italy there are various energy supplier, so the collection of data is now very difficult and a detailed national dataset on consumption is no more available.

Besides, measuring impact of tourism activities on biodiversity requires specific study on the areas under investigation, because every situation has specific characteristics. The assessment of loss of biodiversity due to tourism activities requires one to individuate a representative species for each kind of impact, considering a multiple stress condition. These information is not yet available, so detailed monitoring campaign on flora and fauna of protected areas should be promoted and investigation on number and characteristic of tourists should be carried out to obtain more data useful to measure the disturb caused by tourism activities and to assess carrying capacity of the areas. 


\section{References}

[1] Agarwal, S., The resort cycle revisited: implications for resorts. In C. Cooper and A. Lockwood (eds) Progress in Tourism, Recreation and Hospitality Management, Vol. 5. Chichester: John Wiley and Sons, 1994

[2] Bimonte, S., Punzo, F., A proposito di capacità di carico turistica. Una breve analisi teorica. EdATS Working Papers Series 4, 2005

[3] Beltrame, C., Ciarli, E., Giorgini, E., Maggi, M. Il turismo nell'area del Parco di Crea. Ires Piemonte, 2002

[4] Butler, R. The concept of a tourist area cycle of evolution. Canadian Geographer 24, pp. 5-1, 1980

[5] EEA, Environmental indicators: typology and overview. In: Smeets E, Weterings R (eds) Technical report 25, p 19, 1999

[6] Holling, C.S., Resilience and stability of ecological systems. Annual Review of Ecology and Systematics, 4, pp. 1-23, 1973

[7] Italian national water law, D.lgs 192/99. Gazzetta Ufficiale 145, 1999

[8] INEMAR, www.ambiente.regione.lombardia.it/inemar/inemarhome.htm

[9] May, V., Tourism, the environment, and development: values, sustainability and stewardship. Tourism Management, 12(2), pp. 112-118, 1991

[10] Manning, R.E., How much is too much? Carrying capacity of national parks and protected areas. In: Monitoring and management of visitor flows in recreational and protected areas. Bodenkultur University, Vienna, Austria. p. 306-313, 2002.

[11] Miossec, J.M., Un modèle de l'espace touristique. L'espace géographique: régions, environnement, aménagement, 6(1), pp. 41-48, 1977

[12] WTO, Global code of ethics for tourism. Proc. of Thirteenth session of General Assembly: Santiago, Chile, 1999. 